\title{
Fears, worries, and scary dreams in 4- to 12-year-old children: Their content, developmental pattern, and origins
}

Citation for published version (APA):

Muris, P. E. H. M., Merckelbach, H. L. G. J., Gadet, B. P. M. T., \& Moulaert, V. (2000). Fears, worries, and scary dreams in 4- to 12-year-old children: Their content, developmental pattern, and origins. Journal of Clinical Child Psychology, 29(1), 43-52. https://doi.org/10.1207/S15374424jccp2901_5

Document status and date:

Published: 01/01/2000

DOI:

10.1207/S15374424jccp2901_5

Document Version:

Publisher's PDF, also known as Version of record

Please check the document version of this publication:

- A submitted manuscript is the version of the article upon submission and before peer-review. There can be important differences between the submitted version and the official published version of record.

People interested in the research are advised to contact the author for the final version of the publication, or visit the DOI to the publisher's website.

- The final author version and the galley proof are versions of the publication after peer review.

- The final published version features the final layout of the paper including the volume, issue and page numbers.

Link to publication

\footnotetext{
General rights rights.

- You may freely distribute the URL identifying the publication in the public portal. please follow below link for the End User Agreement:

www.umlib.nl/taverne-license

Take down policy

If you believe that this document breaches copyright please contact us at:

repository@maastrichtuniversity.nl

providing details and we will investigate your claim.
}

Copyright and moral rights for the publications made accessible in the public portal are retained by the authors and/or other copyright owners and it is a condition of accessing publications that users recognise and abide by the legal requirements associated with these

- Users may download and print one copy of any publication from the public portal for the purpose of private study or research.

- You may not further distribute the material or use it for any profit-making activity or commercial gain

If the publication is distributed under the terms of Article $25 \mathrm{fa}$ of the Dutch Copyright Act, indicated by the "Taverne" license above, 


\title{
Fears, Worries, and Scary Dreams in 4- to 12-Year-Old Children: Their Content, Developmental Pattern, and Origins
}

\author{
Peter Muris, Harald Merckelbach, Björn Gadet, and Véronique Moulaert \\ Department of Psychology, Maastricht University
}

\begin{abstract}
Investigated anxiety symptoms in normal school children 4 to 12 years of age $(N=$ 190). The percentages of children reporting fears, worries, and scary dreams were $75.8,67.4$, and $80.5 \%$, respectively, indicating that these anxiety symptoms are quite common among children. Inspection of the developmental pattern of these phenomena revealed that fears and scary dreams were common among 4- to 6-year-olds, became even more prominent in 7- to 9-year-olds, and then decreased in frequency in 10- to 12-year-olds. The developmental course of worry deviated from this pattern. This phenomenon was clearly more prevalent in older children (i.e., 7-to 12-year-olds) than in younger children. Furthermore, although the frequency of certain types of fears, worries, and dreams were found to change across age groups (e.g., the prevalence offears and scary dreams pertaining to imaginary creatures decreased with age, whereas worry about test performance increased with age), the top intense fears, worries, and scary dreams remained relatively unchanged across age levels. An examination of the origins of the se common anxiety phenomena showed that for fears and scary dreams, information was the most commonly reported pathway, whereas for worry, conditioning experiences were more prominent.
\end{abstract}

Fears, worries, and scary dreams seem to be distinct anxiety phenomena. Whereas fear can be described as the unpleasant feeling that arises as a response to realistic danger (Marks, 1987), worry pertains to fearful thought processes (Borkovec, Robinson, Pruzinsky, \& DePree, 1983). Thus, an important difference between these two phenomena is that fear occurs when the participant is actually confronted with a dangerous stimulus or situation, whereas worry takes place in the absence of actual danger and is primarily concerned with thinking about threatening scenarios. Although fears and worries manifest themselves when the person is awake, scary dreams occur during sleep and, hence, should be considered as a separate anxiety phenomenon.

Anxiety phenomena are quite prevalent in children (Craske, 1997). For example, research by Ollendick, King, and colleagues (see, Ollendick, Hagopian \& King, 1997, for a review) has shown that the large majority of children experience fears during their development from infancy to adolescence. The prevalence of worries and nightmares is less documented, but available evidence suggests that these phenomena also frequently occur in children (e.g., Leung \& Robson, 1993;

We thank the teachers, staff, and children of Berg Primary School in Berg en Terblijt, The Netherlands, for their participation in this study. We also thank Amaury Stroux for drawing the anxiety pictures.

Requests for reprints should be sent to Peter Muris, Department of Psychology, Maastricht University, P.O. Box 616,6200 MD Maastricht, The Netherlands. E-mail: p.muris@psychology,unimias.nl
Muris, Meesters, Merckelbach, Sermon, \& Zwakhalen, 1998).

Although it is generally accepted that specific fears, worries, and scary dreams are common among children, relatively little is known about the developmental pattern of these anxiety phenomena (Ollendick \& King, 1994). One exception is a study by Bauer (1976), who examined fears and scary dreams of 4- to 6- , 6- to 8-, and 10- to 12-year-old children. The children were asked to specify what they feared most and to describe their scary dreams. Results showed that $74 \%$ of the $4-$ to 6 -year-olds and $53 \%$ of the 6 - to 8 -year-olds but only $5 \%$ of the 10- to 12 -year-olds reported fears of ghosts and monsters. In contrast, only $11 \%$ of the 4 - to 6-yearolds but $53 \%$ of the 6 - to 8 -year-olds, and $55 \%$ of the 10- to 12-year-olds reported fears of bodily injury and physical danger. Such age-related patterns were also manifest in the descriptions that children provided of their scary dreams. In a similar study by Vasey, Crnic, and Carter (1994), the developmental pattern of childhood worry was investigated. Results indicated that worrisome thoughts become prominent in children after age 7. Furthermore, worries about physical well-being were relatively frequent among 5- to 6-year-old children but then decreased with age, whereas concems about behavioral competence and social evaluation became more prevalent with increasing age. Taken together, in young children, specific fears and scary dreams often involve imaginary creatures (e.g., ghosts) and natural phenomena that occur in their immediate 
environment (e.g., the dark). On the other hand, older children more frequently display worrisome thoughts and specific fears such as blood-injury-illness fears.

Research on the origins of common anxiety symptoms in children is scarce. In fact, only two studies have examined the origins of childhood fears. More specifically, Ollendick and King (1991) evaluated to what extent Rachman's $(1977,1991)$ three-pathways-to-fear (conditioning, modeling, and exposure to negative information) model can be applied to common childhood fears. Children were given a brief questionnaire concerning their fears that asked them to indicate (a) whether they remembered bad or frightening experiences in relation to these fears (i.e., conditioning); (b) whether they observed parents, friends, or other acquaintances displaying these fears (i.e., modeling); and (c) whether they heard frightening things about their feared objects and situations from other people or from television (i.e., information). Ollendick and King (1991) found that a large majority (88.8\%) of children attributed their fear to exposure to negative information. Modeling and conditioning pathways were less often endorsed by the children ( 56.2 and $35.7 \%$, respectively). In a more recent study, Muris, Merckelbach, and Collaris (1997) sought to replicate these findings. Inspired by critical analyses of the three-pathways-to-fear research (e.g., Menzies \& Clarke, 1994), these authors used more stringent definitions of conditioning, modeling, and information pathways. That is, children were explicitly asked to what extent such experiences actually had contributed to the onset or severity of their fear. The results were markedly different from those reported by Ollendick and King (1991). Muris, Merckelbach, and Collaris (1997) found conditioning to be the most prominent pathway (45.8\%), followed by exposure to negative information (35.1\%), and modeling (only $3.8 \%$ ).

There is tentative evidence to suggest that Rachman's $(1977,1991)$ three-pathways model may also be relevant to the origins of worry and scary dreams. Most of this evidence focuses on the role of conditioning in the etiology of these anxiety symptoms. For example, in a recent study by Muris et al. (1998), a substantial minority of the children (nearly $30 \%$ ) was found to report that their main worry became more intense after having experienced an aversive event or was even caused by such an event. Likewise, it is well documented that frightening dreams may occur in children who have been confronted with a traumatic event (e.g., AmayaJackson \& March, 1995). Yet, so far, the role of modeling and exposure to negative information in the development of worrisome thoughts and scary dreams has not been systematically examined.

In this survey, fears, worries, and scary dreams of normal children 4 to 12 years of age were investigated. The first purpose was to examine the developmental pattern of these anxiety phenomena. A second aim was to assess to what extent conditioning, modeling, and negative information contribute to the etiology of common anxiety symptoms in children.

\section{Method}

\section{Children}

The sample consisted of 190 children $(92$ boys and 98 girls) who were recruited from a regular primary school. Written informed consent was obtained from parents and children before participation in the study; approximately $70 \%$ of those invited to participate in the study agreed. Ages of the children ranged between 4 and 12 years. There were at least 15 children of each age. Mean age of the total sample was 7.88 years $(S D=$ 2.31). The large majority of the children (90\%) was Caucasian; the remaining $10 \%$ was Asian or North African. Percentages of children with low, middle, or upper socioeconomic background (these figures were anonymously provided by the staff of the school and based on the occupational levels of both parents) were 20,40 , and $40 \%$, respectively. About $15 \%$ of the children came from divorced families.

\section{Interview}

The interview lasted for about $15 \mathrm{~min}$ and consisted of three parts, each referring to one of the following anxiety phenomena: fears, worries, or scary dreams. For each anxiety phenomenon, the procedure was identical and started by showing the child a picture and describing it briefly (see Appendix). Pictures and descriptions were used to make the anxiety phenomena more comprehensible to the younger children. Before the start of the study, the senior author tested the interview with young children of several ages (between 4 and 6 years). Children appeared to understand the questions and produced sensible answers.

After presenting the picture, children were questioned about the frequency with which they experienced that particular anxiety phenomenon. For example, following presentation of the scary dream picture, children were asked, "How often do you have a scary dream?" (frequency; 1 = never, 2 = sometimes, or $3=$ often). Only children who indicated that the anxiety phenomenon was present, that is, children who answered with sometimes or often to the frequency question, were invited to provide details about content and severity. In the case of scary dreams, the questions were "What is that scary dream about?" (content), and "When you wake up from this dream, how anxious are you then?" (severity; $1=$ not at all anxious, $2=$ somewhat anxious, $3=$ very anxious). These children were also interviewed about the 
origins of the anxiety phenomenon. Separate questions were asked about conditioning events (e.g., "Did you ever experience a frightening event with [the content of the scary dream]?"), modeling (e.g., "Have you seen other people being afraid of [the content of the scary dream]?"), and negative information (e.g., "Did you see frightening things on television about [the content of the scary dream]?"). In passing, it should be noted that conditioning, modeling, and information were defined employing the stringent criteria proposed by Muris, Merckelbach, and Collaris (1997; see introduction). In the case of fears and worries, identical questions about content, severity, and origins were asked, this time with regard to children's main fear and worry.

\section{Procedure}

Children were interviewed individually in a private room. They were explicitly told that the information they provided would remain confidential. The interviews were conducted by two research assistants (one man and one woman), who interviewed an equal number of boys and girls in each age level. Research assistants were graduate students in clinical psychology who had experience in interviewing preschool and primary school children. The assistants were trained in conducting the interview by the senior author. During the training phase, each research assistant carried out the interview with five children. These cases were supervised by Peter Muris; they were discussed in detail, and disagreements were resolved.

To avoid systematic carryover effects, interview parts were counterbalanced across the children. Thus, some children were first asked questions about their fears, then they were interviewed about their worries, and finally they were questioned about their scary dreams. Other children received the interview parts in a different order.

\section{Data Analysis}

The Statistical Package for Social Sciences (SPSS Inc., 1998) was used to calculate descriptive statistics (frequencies, percentages) and to evaluate differences between age groups, anxiety phenomena, and sexes by means of chi-square tests (when cells with low frequencies were analyzed, Fischer exact tests were employed) and analyses of variance. It is important to note that, for the most part, data showed similar results for boys and girls. Therefore, with few exceptions, only the findings for the total group are discussed in the Results section.

\section{Results}

\section{Content of Fears, Worries, and Scary Dreams}

The percentages of children reporting fears, worries, and scary dreams were $75.8,67.4$, and $80.5 \%$, respectively. This indicates that these anxiety phenomena are relatively common in normal children. Tables 1,2 , and 3 show rank orders of fears, worries, and scary dreams of the children. As can be seen, the most common fears concerned animals $(n=41,21.6 \%$ of the total sample; e.g., snakes, spiders, dogs, crocodiles, lions, tigers, wolves), imaginary creatures ( $n=24,12.6 \%$; e.g., witches, ghosts, monsters), being kidnapped ( $n=15$, $7.9 \%$ ), and social threats ( $n=15,7.9 \%$; e.g., being teased). The most frequent worries were about harm ( $n$ $=32,16.8 \%$; e.g., accident), death $(n=28,14.8 \%)$, test

Table 1. Rank Order of Specific Fears Reported by the Children

\begin{tabular}{|c|c|c|c|c|c|c|}
\hline \multirow[b]{2}{*}{ Fear } & \multicolumn{2}{|c|}{ Total Group } & \multicolumn{2}{|c|}{ Boys ${ }^{b}$} & \multicolumn{2}{|c|}{ Girls $^{\mathrm{c}}$} \\
\hline & Frequency & $\%$ & Frequency & $\%$ & Frequency & $\%$ \\
\hline 1. Animals & 41 & 21.6 & 21 & 22.8 & 20 & 20.4 \\
\hline 2. Imaginary Creatures & 24 & 12.6 & 15 & 16.3 & 9 & 9.2 \\
\hline 3. Being Kidnapped & 15 & 7.9 & 3 & 3.2 & 12 & $12.2 *$ \\
\hline Social Threats & 15 & 7.9 & 7 & 7.6 & 8 & 8.2 \\
\hline 4. Frightening Dreams or Movies & 13 & 6.8 & 8 & 8.7 & 5 & 5.1 \\
\hline 5. Environmental Threats & 12 & 6.3 & 7 & 7.6 & 5 & 5.1 \\
\hline 6. Personal Harm or Harm to Others & 7 & 3.7 & 2 & 2.2 & 5 & 5.1 \\
\hline 7. Burglar & 6 & 3.2 & 3 & 3.3 & 3 & 3.1 \\
\hline 8. Medical Procedures & 5 & 2.6 & 2 & 2.2 & 3 & 3.1 \\
\hline 9. Dying or Death of Others & 4 & 2.1 & 1 & 1.1 & 3 & 3.1 \\
\hline 10. Test Performance & 1 & 0.5 & 0 & 0.0 & 1 & 1.0 \\
\hline Separation From Parents & 1 & 0.5 & 1 & 1.1 & 0 & 0.0 \\
\hline No Fear & 46 & 24.2 & 22 & 23.9 & 24 & 24.5 \\
\hline
\end{tabular}

${ }^{\mathrm{a}} N=190 .{ }^{\mathrm{b}} n=92 .{ }^{c_{n}} n=98$.

*Difference between boys and girls significant at $p<.05$. 
Table 2. Rank Order of Worries Reported by the Children

\begin{tabular}{|c|c|c|c|c|c|c|}
\hline \multirow[b]{2}{*}{ Worry } & \multicolumn{2}{|c|}{ Total Group ${ }^{a}$} & \multicolumn{2}{|c|}{ Boys ${ }^{\text {b }}$} & \multicolumn{2}{|c|}{ Girls $s^{c}$} \\
\hline & Frequency & $\%$ & Frequency & $\%$ & Frequency & $\%$ \\
\hline 1. Personal Harm or Harm to Others & 32 & 16.8 & 15 & 16.3 & 17 & 17.3 \\
\hline 2. Dying or Death of Others & 28 & 14.8 & 11 & 12.0 & 17 & 17.3 \\
\hline 3. Test Perfomance & 26 & 13.7 & 12 & 13.0 & 14 & 14.3 \\
\hline 4. Separation From Parents & 10 & 5.3 & 5 & 5.4 & 5 & 5.1 \\
\hline 5. Frightening Dreams or Movies & 6 & 3.2 & 2 & 2.2 & 4 & 4.1 \\
\hline Social Threats & 6 & 3.2 & 2 & 2.2 & 4 & 4.1 \\
\hline Burglar & 6 & 3.2 & 2 & 2.2 & 4 & 4.1 \\
\hline G. Being Kidnapped & 5 & 2.6 & 1 & 1.1 & 4 & 4.1 \\
\hline 7. Being Punished & 3 & 1.6 & 3 & 3.3 & 0 & $0.0^{*}$ \\
\hline Imaginary Creatures & 3 & 1.6 & 2 & 2.2 & 1 & 1.0 \\
\hline 8. Medical Procedures & 2 & 1.1 & 1 & 1.1 & 1 & 1.0 \\
\hline 9. Animals & 1 & 0.5 & 0 & 0.0 & 1 & 1.0 \\
\hline No Worry & 62 & 32.6 & 36 & 39.1 & 26 & 26.5 \\
\hline
\end{tabular}

" $N=190 .{ }^{b} n=92 .{ }^{c} n=98$.

*Difference between boys and girls significant at $p<.05$.

Table 3. Rank Order of Scary Dreams Reported by the Children

\begin{tabular}{|c|c|c|c|c|c|c|}
\hline \multirow[b]{2}{*}{ Scary Dream } & \multicolumn{2}{|c|}{ Total Group ${ }^{\mathrm{a}}$} & \multicolumn{2}{|c|}{ Boys ${ }^{b}$} & \multicolumn{2}{|c|}{ Girls $^{\mathfrak{c}}$} \\
\hline & Frequency & $\%$ & Frequency & $\%$ & Frequency & $\%$ \\
\hline 1. Imaginary Creatures & 56 & 29.5 & 28 & 30.4 & 28 & 38.6 \\
\hline 2. Personal Harm or Harm to Others & 33 & 17.3 & 15 & 16.3 & 18 & 18.4 \\
\hline 3. Being Kidnapped & 28 & 14.7 & 13 & 14.1 & 15 & 15.3 \\
\hline 4. Animals & 13 & 6.8 & 8 & 8.7 & 5 & 5.1 \\
\hline Dying or Death of Others & 13 & 6.8 & 4 & 4.3 & 9 & 9.2 \\
\hline 5. Burglar & 5 & 2.6 & 4 & 4.3 & 1 & 1.0 \\
\hline 6. Separation From Parents & 4 & 2.1 & 1 & 1.1 & 3 & 3.1 \\
\hline 7. Social Threats & 1 & 0.5 & 0 & 0.0 & 1 & 1.0 \\
\hline No Scary Dream & 37 & 19.5 & 19 & 20.7 & 18 & 18.4 \\
\hline
\end{tabular}

${ }^{\mathrm{a}} N=190 . \mathrm{b}_{n}=92 . \mathrm{c}_{n}=98$.

performance at school $(n=26,13.7 \%)$, and being separated from parents $(n=10,5.3 \%)$. The most prevalent scary dreams were about imaginary creatures $(n=56$, $29.5 \%)$, harm $(n=33,17.3 \%)$, being kidnapped $(n=28$, $14.7 \%)$, dangerous animals $(n=13,6.8 \%)$, and death $(n$ $=13,6.8 \%)$.

A tendency was found for worry to be somewhat more prevalent among girls. Percentages of children who reported to worry every now and then were $73.5 \%$ for girls versus $60.9 \%$ for boys, $\chi^{2}(1, N=190)=3.40, p$ $=.06$. Furthermore, as can be seen in Tables 1 to 3 , more girls than boys were afraid of being kidnapped, $\chi^{2}(1, N$ $=190)=5.43, p<.05$, whereas more boys than girls worried about being punished, $\chi^{2}(1, N=190)=4.00, p$ $<.05$.

\section{Developmental Patterns}

To examine the developmental patterns of fears, worries, and scary dreams, the sample was divided into three age groups: (a) children 4,5 , and 6 years of age $(n=62)$; (b) children 7,8 , and 9 years of age $(n=$ 69); and (c) children 10,11 , and 12 years of age $(n=$ 59). This division was primarily based on children's level of cognitive development, which is considered to have influence on the experience of anxiety (see Muris \& Merckelbach, in press). Children ages 4 to 6 were treated as a separate group because, according to Piaget's (see e.g., Flavell, Miller \& Miller, 1993) cognitive developmental theory, these children are still in the preoperational stage. During this stage, cognitive abilities are restricted, so anxiety is concerned with immediate, concrete threats. In addition, children in this stage are prone to magical thinking, and this will result in fears of imaginary creatures. From age 7 , children enter the so-called concrete operational stage. During this stage (which lasts until about age 12), children are increasingly able to infer physical cause-effect relationships and to anticipate potential negative outcomes, thereby broadening the range of fear-provoking stimuli. To study whether anxiety phenomena change during this stage, children were divided in two groups, 7- to 9-year-olds and 10- to 12-year-olds. 
Chi-square tests were carried out to compare the prevalence of anxiety phenomena across the three age groups. As shown in Table 4, fears and nightmares exhibited an almost identical developmental pattern. That is, these phenomena were commonly reported by $4-$ to 6-year-olds ( 71.0 and $67.7 \%$, respectively), became even more prevalent in 7- to 9-year-olds ( 87.0 and $95.7 \%$, respectively), and were then found to return to initial levels among 10- to 12-year-olds (67.8 and $76.3 \%$, respectively). The prevalence rates of worry followed a somewhat different developmental course. About half of the 4- to 6-year-old children (46.8\%) reported that they had worrisome thoughts. This percentage was found to be significantly higher in 7- to 9-yearolds $(78.3 \%)$ and remained relatively stable among $10-$ to 12 -year-olds (76.3\%).

Additional analyses revealed that the developmental patterns of fears and scary dreams were highly similar among boys and girls. However, a sex difference was found with regard to the developmental course of worry. In 4- to 6-year-olds, the prevalence rate of worry was highly comparable in both sexes ( $48.3 \%$ in girls vs, $45.5 \%$ in boys). Yet, in 7- to 9year-olds, worry was found to be significantly more prevalent in girls than in boys: percentages were 88.9 versus $66.7 \%$, respectively, $\chi^{2}(1, N=69)=5.00, p<$ .05 . Among 10 - to 12-year-olds, worry appeared to have decreased in girls, whereas it had further increased in boys, resulting in comparable but still relatively high prevalence rates for both sexes $(78.8 \%$ vs. $73.1 \%$, respectively).
Table 5 presents the top intense fears, worries, and scary dreams for each age group. As shown, the top intense fears, worries, and scary dreams remained relatively stable across age levels. However, there were some interesting exceptions. For example, whereas separation from parents was the top intense worry in 4- to 6-year-old children (24.1\%), this type of concern did no longer feature in the top 3 among 7- to 9year-olds $(5.6 \%)$ and 10 - to 12-year-olds $(0.0 \%)$, $\chi^{2}(2, N=128)=14.93, p<.005$. The opposite pattern was found for worry about test performance. That is, whereas none $(0.0 \%)$ of the 4- to 6-year-old children worried about this topic, this type of worry was observed in nearly half (46.7\%) of the 10 - to 12 year-old children, $\chi^{2}(2, N=128)=30.78, p<.001$. Finally, fears and scary dreams about imaginary creatures were found to decrease gradually with age. Percentages for 4- to 6-, 7- to 9-, and 10- to 12-year-olds were $31.8,13.3$, and $5.0 \%$, respectively, for fears, $\chi^{2}(2, N=144)=11.67, p<.005$, and 61.9, 30.3, and $22.2 \%$, respectively, for scary dreams $\chi^{2}(2, N=153)$ $=16.73, p<.00 \mathrm{l}$.

\section{Origins of Fears, Worries, and Scary Dreams}

Figure 1 shows the percentages of children who reported information, modeling, and conditioning experiences as important etiological factors in the origins of their top intense fear, worry, or scary dream. As can be

Table 4. Prevalence Rates (Percentages) of Fears, Worries, and Scary Dreams for the Three Different Age Groups

\begin{tabular}{lcccrr}
\hline & \multicolumn{3}{c}{ Age Group (Years) } & & \\
\cline { 2 - 5 } Anxiety Phenomenon & $\mathbf{4 - 6}$ & $\mathbf{7 - 9}$ & $\mathbf{1 0 - 1 2}$ & $\chi^{2}(2, N=190)$ & \multicolumn{1}{c}{$\boldsymbol{p}$} \\
\hline Fears & $71.0_{\mathrm{a}}$ & $87.0_{\mathrm{b}}$ & $67.8_{\mathrm{a}}$ & 7.53 & $<.050$ \\
Worry & $46.8_{\mathrm{a}}$ & $78.3_{\mathrm{b}}$ & $76.3_{\mathrm{b}}$ & 17.81 & $<.001$ \\
Scary Dreams & $67.7_{\mathrm{a}}$ & $95.7_{\mathrm{b}}$ & $76.3_{\mathrm{a}}$ & 17.21 & $<.001$ \\
\hline
\end{tabular}

Note: Within each row, percentages with different subscripts differ at $p<.05$ (post hoc comparisons).

Table 5. Top Intense Fears, Worries, and Scary Dreams for Each Age Group

\begin{tabular}{|c|c|c|c|}
\hline \multirow[b]{2}{*}{ Anxiety Phenomenon } & \multicolumn{3}{|c|}{ Age Group (Years) } \\
\hline & $4-6$ & $7-9$ & $10-12$ \\
\hline Fears & $\begin{array}{l}\text { 1. Animals } \\
\text { 2. Imaginary creatures } \\
\text { 3. Environmental threats }\end{array}$ & $\begin{array}{l}\text { 1. Animals } \\
\text { 2. Imaginary creatures } \\
\text { 3. Frightening dreams or movies }\end{array}$ & $\begin{array}{l}\text { 1. Animals } \\
\text { 2. Social threats } \\
\text { 3. Being kidnapped }\end{array}$ \\
\hline Worries & $\begin{array}{l}\text { 1. Separation from parents } \\
\text { Dying or deatl of others } \\
\text { 2. Burglar } \\
\text { Personal harm or harm to others }\end{array}$ & $\begin{array}{l}\text { 1. Personal harm or harm to others } \\
\text { 2. Dying or death of others } \\
\text { 3. Test performance }\end{array}$ & $\begin{array}{l}\text { 1. Test performance } \\
\text { 2. Dying or death of others } \\
\text { 3. Personal harm or harm to others }\end{array}$ \\
\hline Scary Dreams & $\begin{array}{l}\text { 1. Imaginary creatures } \\
\text { 2. Personal harm or harm to others } \\
\text { 3. Animals }\end{array}$ & $\begin{array}{l}\text { 1. Imaginary creatures } \\
\text { 2. Being kidnapped } \\
\text { 3. Personal harm or harm to others }\end{array}$ & $\begin{array}{l}\text { 1. Being kidnapped } \\
\text { 2. Imaginary creatures } \\
\text { 3. Personal harm or harm to others }\end{array}$ \\
\hline
\end{tabular}




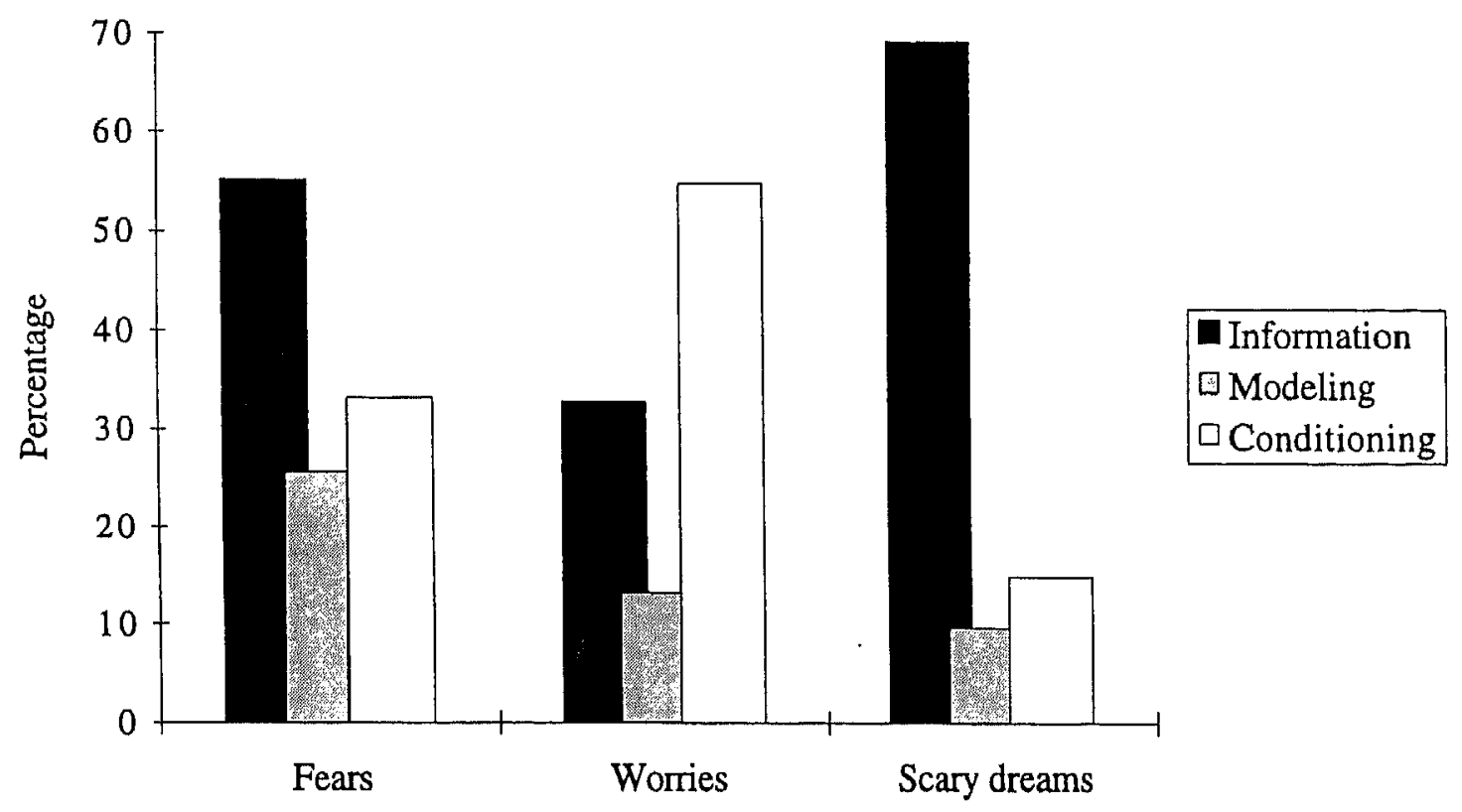

Figure 1. Percentages of children reporting conditioning, modeling, and information experiences in relation to their main fears, worries, and scary dreams.

seen, more than half $(55.2 \%)$ of the children attributed their main fear to exposure to negative information. Percentages of children who endorsed conditioning and modeling pathways in relation to their fear were considerably lower: 33.1 and $25.5 \%$, respectively.

The majority $(54.7 \%$ ) of the children ascribed the origin of their main worry to a conditioning experience (e.g., "My worrisome thoughts about death began when Grandmother died last year"), $32.8 \%$ reported an information pathway (e.g., "My worry about being kidnapped became worse after seeing a kidnapper on the television news"), and only $13.3 \%$ mentioned a modeling experience (e.g., "My mother also worries a lot about my little sister's health").

As to the origins of scary dreams, a vast majority (69.3\%) of the children indicated the information pathway. That is, most children said that these dreams were about some frightening thing that they had recently seen on television. Only a small percentage of the children mentioned modeling (e.g., "I dream about dogs ever since seeing my mother being very afraid of a dog") or conditioning experiences (e.g., "I dream about being hit by a car since I was involved in an accident a few months ago") in relation to their scary dreams ( 9.8 and $15.0 \%$, respectively).

Additional chi-square tests were carried out to investigate whether children's descriptions of the origins of the anxiety phenomena differed across the three age groups. These analyses showed that children of different ages were relatively stable in describing the origins of their fears, worries, and scary dreams in terms of the three pathways. Only in the case of worry did a signifi- cant effect of age emerge: Four- to 6-year-old children more frequently endorsed the information pathway in relation to their main worry than 7- to 9- and 10- to 12year-old children $(55.2,29.6$, and $22.2 \%$, respectively), $\chi^{2}(2, N=128)=9.11, p=.01$.

\section{Comparisons Among \\ Fears, Worries, and Scary Dreams}

Content. Comparisons among prevalence rates of separate fears, worries, and scary dreams revealed that the content of these anxiety phenomena differed significantly. Thus, fears typically involved animals and environmental threats; worries were predominantly concerned with death, test performance, separation from parents, and being punished; and scary dreams often pertained to imaginary creatures and being kidnapped (see upper rows of Table 6).

Characteristics. Both frequency and severity of fears, worries, and scary dreams reported by the children were rated on 3-point scales (cf. supra). Scary dreams were found to be the most frequent phenomenon $(M=2.04, S D=0.65)$, followed by fears $(M=1.89$, $S D=0.60)$, and worries $(M=1.76, S D=0.59)$. Severity scores did not differ among fears, worries, and scary dreams; means varied between 2.14 and 2.26 , indicating these anxiety phenomena were accompanied by moderate levels of anxiety. In passing, it should be noted that no significant effects of age groups or sex were found with regard to the severity scores. 
Table 6. Comparisons among Specific Fears, Worries, and Scary Dreams in Terms of Content, Characteristics, and Pathways of Acquisition

\begin{tabular}{|c|c|c|c|c|c|}
\hline & Fears ${ }^{\mathrm{a}}$ & Worries ${ }^{b}$ & $\begin{array}{c}\text { Scary } \\
\text { Dreams }^{\mathfrak{c}}\end{array}$ & $\chi^{2}$ or $F$ & $p$ \\
\hline \multicolumn{6}{|l|}{ Content } \\
\hline Animals & $28.5_{\mathfrak{a}}$ & $0.8_{\mathrm{b}}$ & $8.5_{\mathrm{c}}$ & 50.31 & $<.001$ \\
\hline Social Threats & $10.4 \mathrm{a}$ & $4.7 \mathrm{a}$ & $0.6_{\mathrm{b}}$ & 14.58 & $<.005$ \\
\hline Environmental Threats & $8.3_{\mathrm{a}}^{4}$ & $0.0_{b}$ & $0.0_{\mathrm{b}}$ & 24.10 & $<.001$ \\
\hline Frightening Dreams or Movies & $9.0_{\mathrm{a}}$ & $4.7_{\mathrm{a}}$ & $0.0_{\mathrm{b}}$ & 14.18 & $<.005$ \\
\hline Medical Procedures & 3.5 & $1.6^{4}$ & 0.0 & $5.5 !$ & $n s$ \\
\hline Burglar & 4.2 & 4.7 & 3.3 & 0.38 & $n s$ \\
\hline Dying or Death of Others & $2.8_{\mathrm{a}}$ & $21.9_{\mathrm{b}}$ & $8.5_{c}$ & 27.21 & $<.001$ \\
\hline Test Performance & $0.7_{\mathrm{a}}$ & $20.3_{\mathrm{b}}$ & $0.0_{\mathrm{a}}$ & 60.26 & $<.001$ \\
\hline Personal Harm or Harm to Others & $4.9 \mathrm{a}$ & $25.0_{\mathrm{b}}$ & $19.6_{\mathrm{b}}$ & 22.20 & $<.001$ \\
\hline Separation From Parents & $0.7_{a}$ & $7.8_{b}$ & $2.6_{\mathrm{a}}$ & 10.67 & $<.010$ \\
\hline Being Punished & $0.0^{\prime \prime}$ & $2.3_{\mathrm{b}}$ & $0.0_{\mathrm{a}}$ & 7.01 & $<.050$ \\
\hline Imaginary Creatures & $16.7_{a}$ & $2.3_{\mathrm{b}}$ & $36.6_{\mathrm{c}}$ & 53.18 & $<.001$ \\
\hline Being Kidnapped & $10.3_{a}$ & $3.8_{\mathrm{b}}$ & $20.3_{\mathrm{c}}$ & 18.56 & $<.001$ \\
\hline \multicolumn{6}{|l|}{ Characteristic } \\
\hline Frequency $(M, S D)$ & $1.89(0.60)_{\mathrm{a}}$ & $1.76(0.59)_{b}$ & $2.04(0.65)_{c}$ & 9.73 & $<.001$ \\
\hline Severity $(M, S D)$ & $2.26(0.56)$ & $2.23(0.58)$ & $2.14(0.63)$ & 1.67 & $n s$ \\
\hline \multicolumn{6}{|l|}{ Pathway } \\
\hline Information & $55.2_{a}$ & $32.8_{\mathrm{b}}$ & $69.3_{\mathrm{c}}$ & 37.50 & $<.001$ \\
\hline Modeling & $25.5_{\mathrm{a}}$ & $13.3_{\mathrm{b}}$ & $9.8 b$ & 14.69 & $<.001$ \\
\hline Conditioning & $33.1_{a}$ & $54.7_{\mathrm{b}}$ & $15.0_{\mathrm{c}}$ & 49.24 & $<.001$ \\
\hline
\end{tabular}

Note: Percentages in Frequency row are calculated on the basis of the total sample: $N=190$. Within each row, means percentages with different subscripts differ at $p<.05$ (post hoc comparisons).

$\mathrm{a}_{n}=144, \mathrm{~b}_{n=128}, c_{n=1} 153$.

Pathways. As can be seen in the lower rows of Table 6, the information pathway was the most commonly reported pathway for scary dreams, modeling was the most frequently mentioned pathway for fears, and conditioning was the most predominant mode for worries.

\section{Discussion}

In this study, fears, worries, and scary dreams of normal children 4 to 12 years of age were examined. The main results can be cataloged as follows. To begin with, percentages of children reporting fears, worries, and scary dreams were $75.8,67.4$, and $80.5 \%$, respectively, indicating that these anxiety phenomena are quite common among children. Second, inspection of the developmental pattern of these anxiety phenomena revealed that fears and scary dreams were fairly common among 4- to 6-year-olds, became even more prominent in 7- to 9-year-olds, and then returned to previous levels in 10- to 12-year-olds. The developmental course of worry deviated from this pattern in that a higher prevalence of worrisome thoughts was found in older children (i.e., after age 7) versus younger children. Third, although the prevalence of some specific types of fears, worries, and dreams changed across age groups (e.g., the frequency of fears and scary dreams about imaginary creatures decreased with age, whereas worry about test performance increased with age), the top intense fears, worries, and scary dreams remained relatively stable across age levels. Fourth, in fears and scary dreams, information was found to be the most commonly reported pathway, whereas in worry, conditioning experiences were more prominent. Fifth and finally, a comparison among fears, worries, and scary dreams revealed significant differences with respect to content and origins, suggesting that they reflect separate anxiety phenomena.

By and large, these results fit well with those of previous studies. For example, the rank orders found in this study are highly similar to those found in earlier surveys of childhood fears (Muris, Merckelbach, \& Collaris, 1997; Muris, Merckelbach, Mayer, \& Prins, in press; Muris, Merckelbach, Meesters, \& Van Lier, 1997) and worries (Muris et al., 1998; Silverman, La Greca, \& Wasserstein, 1995). Furthermore, these data replicate the developmental patterns of these anxiety phenomena. For example, in line with Bauer (1976), it was found that the frequency of fears and scary dreams about imaginary creatures decreases with age. Likewise, as in the Vasey et al. (1994) study, the prevalence of worries about test performance was found to increase with age.

With regard to the origins of childhood fears, it is worthy to note that the distribution of pathways found in this study deviated from that obtained in previous research. For example, Ollendick and King (1991) found that a majority of children attributed their fear to negative information $(88.8 \%$ of the children reported such 
experiences), whereas modeling and conditioning events were less often mentioned by the children ( 56.2 and $35.7 \%$, respectively). These percentages differ considerably from those found in this study. However, as mentioned in the Introduction, Ollendick and King (1991) employed broad definitions of the three types of learning experiences. For this reason, it seems more appropriate to compare these findings with those of Muris, Merckelbach, and Collaris (1997), who employed similar criteria to define the three pathways. Such a comparison reveals that the percentage of children in this study who reported conditioning experiences in relation to their main fear was lower than that found by Muris, Merckelbach, and Collaris (1997; 33.1 vs. $45.8 \%$, respectively). Otherwise, in this survey, children more often indicated that negative information was involved in the etiology of their main fear compared to the percentage found in the Muris, Merckelbach, and Collaris (1997) study (55.2 vs. $35.1 \%$ ). There is a straightforward explanation for these differences. That is, whereas this study was concerned with children ages 4 to 12 , the Muris, Merckelbach, and Collaris (1997) study relied on a sample of 8- to 12-year-old children. Thus, this survey also included younger children. Keeping in mind that these young children frequently report fears of imaginary creatures (31.8\% of the 4- to 6-year-olds in this study) and the fact that these fears are often attributed to an information pathway (78.6\%) and only rarely ascribed to conditioning ( $7.1 \%$ ), the distribution of etiological pathways found in this study makes sense.

Scary dreams were most frequently associated with an information pathway. That is to say, almost $70 \%$ of the children reported that they had frightening dreams about something they had seen on television. This result is in agreement with a previous study by Viemero and Paajanen (1992). These authors found that in 8- to 10-year-old children, there is a positive relationship between exposure to television violence and aggressive dreams and fantasies. These data suggest that not only aggressive but also frightening television themes may surface in children's dreams.

Although a considerable proportion (46.8\%) of the 4- to 6-year-old children reported that they worried every now and then (see also Stevenson-Hinde \& Shouldice, 1995), this anxiety problem became more frequent in older children (almost $80 \%$ ). Vasey and Daleiden (1994) argued that worry becomes increasingly prominent in children after age 7 because their ability to reason about future possibilities, to consider multiple threatening outcomes, and to elaborate potential negative consequences dramatically increases.

Previous research has shown that girls generally display higher levels of fears and anxiety symptoms than boys (for a comprehensive review of this topic, see Craske, 1997). In line with this, this study found that 7 to 9 -year-old girls worried more frequently than boys of this age. The absence of further sex differences may have to do with the measures that were used in this study. For example, frequency and severity of anxiety phenomena were assessed by means of a single 3-point scale. It is possible that these crude measures are not sensitive enough to detect sex differences.

Several limitations of this study should be acknowledged. First of all, the study solely relied on children's self-report of fears, worries, and scary dreams. Additional interviews with the parents would have yielded additional information about the content, developmental pattern, and origins of these anxiety phenomena. Second, the study only employed interviews and did not use any standardized self-report measures of fears, worries, and scary dreams. Although there are currently no measures for tapping anxiety symptoms in children of age 6 and younger, the older children in this study could have completed self-report measures (e.g., the Fear Survey Schedule for Children; Ollendick, 1983) as a means of validating the interview. Third, no systematic data were obtained regarding the integrity of the interview. It should be stressed, however, that even the younger children in this study seemed to understand the interview questions and produced sensible ans wers. Fourth, the pictures that were used in this study depicted boys, and it is possible that girls were less able to relate to the pictures. Note that this may have contributed to the finding that there were fewer sex differences than might otherwise have been expected (see earlier discussion). Finally, this study relied on a cross-sectional research design. Of course, a longitudinal set-up, in which children are followed for several years, would provide a more valid picture about the developmental course of these anxiety phenomena (for an extensive discussion of this topic, see Ollendick \& King, 1994)

Despite the high prevalence of childhood anxiety problems like fears, worries, and scary dreams, little is known about their severity. Recent studies by Muris and colleagues (Muris et al., 1998; Muris et al., in press) indicate that, for a substantial minority of children, fears and worries may acquire a clinical intensity. The etiological mechanisms that explain how normal, developmental anxiety phenomena transform into clinical symptoms remain largely unknown, although there is, at least in the case of spider phobia, reason to believe that conditioning experiences play an important role in the radicalization of fears (e.g., Muris, Merckelbach, \& Collaris, 1997; Merckelbach \& Muris, 1997; Merckelbach, Muris, \& Schouten, 1996). In more general terms, there has been a tendency in the literature to portray common childhood fears (including worries and dreams) as spontaneous or nonassociative developmental phenomena that occur in the absence of pertinent learning experiences (e.g., Menzies \& Clarke, 1995). These results, as well as those of Muris, Merckelbach, and Collaris (1997) and Ollendick and King (1991), suggest that conditioning, modeling, and informational experiences contribute to the manifesta- 
tions of common anxiety phenomena in childhood (see for a review, King, Gullone, \& Ollendick, 1998). The precise details of how these pathways interact with common anxiety phenomena require further study. There are several possibilities (see Merckelbach, De Jong, Muris \& Van den Hout, 1996). It might well be the case that these learning experiences are responsible for the very onset of common anxiety phenomena, but it is also possible that they are superimposed on developmental fears and contribute to a radicalization of those fears. Obviously, these possibilities can only be evaluated with longitudinal studies.

Knowledge about the etiology of fears, worry, and scary dreams may also be of relevance for the treatment of children who suffer severely from these anxiety phenomena. There is some tentative evidence that the pathway along which an anxiety phenomenon has been acquired determines the type of treatment. For example, whereas conditioned-based phobias would be most effectively treated with exposure, modelingand information-based phobias would call for cognitive interventions (Öst, 1985). In the past years, the arsenal of effective treatment programs for childhood anxiety problems has been considerably enlarged (Ollendick \& King, 1998). It would be interesting to examine whether the effectiveness of these treatment programs can be optimized by taking pathway of acquisition into account.

\section{References}

Amaya-Jackson, L., \& March, J. S. (1995). Posttraumatic stress disorder. In J. S. March (Ed.), Anxiety disorders in children and adolescents (pp. 276-300). New York: Guilford.

Bauer, D. H. (1976). An exploratory study of developmental changes in children's fears. Journal of Chlld Psychology and Psychiatry, $17,69-74$.

Borkovec, T. D., Robinson, E., Pruzinsky, T., \& DePree, J. A. (1983). Preliminary exploration of worry: Some characteristics and processes. Behaviour Research and Therapy, 21, 9-16.

Craske, M. G. (1997). Fear and anxiety in children and adolescents. Bulletin of the Menninger Clinic, 61, 4-34.

Flavell, J. H., Miller, P. H., \& Miller, S. A. (1993). Cognitive development. Englewood Cliffs, NJ: Prentice Hall.

King, N. J., Gullone, E., \& Ollendick, T. H. (1998). Etiology of childhood phobias: Current status of Rachman's three pathways theory. Behaviour Research and Therapy, 36, 297-309.

Leung, A. K. C., \& Robson, W. L. M. (1993). Nightmares. Joumal of the National Medical Association, 85, 233-235.

Marks, I. M. (1987). Fears, phobias, and rituals. Panic, anxiety, and their disorders. New York: Oxford University Press.

Menzies, R. G., \& Clarke, J. C. (1994). Retrospective studies of the origins of phobias: A review. Artriety, Stress, and Coping, 7, 305-318.

Menzies, R. G., \& Clarke, J. C. (1995). The etiology of phobias: A nonassociative account. Clinical Psychology Review, 15, 23-48.

Merckelbach, H., De Jong, P. J., Muris, P., \& Van den Hout, M. A. (1996). The etiology of specific phobias: A review. Clinical Psychology Review, 16, 337-361.

Merckelbach, H., \& Muris, P. (1997). The etiology of childhood spider pliobia. Behaviour Research and Therapy, 35, 1031-1034.
Merckelbach, H., Muris, P., \& Schouten, E. (1996). Pathways to fear in spider phobic children. Behaviour Research and Therapy, 34, 935-938.

Muris, P., Meesters, C., Merckelbach, H., Sermon, A., \& Zwakhalen, S. (1998). Worry in normal children. Joumal of the American Academy of Child \& Adolescent Psychiatry, 37, 703-710.

Muris, P., \& Merckelbach, H. (in press). The etiology of childhood specific phobia: A multifactorial model. In M. W. Vasey \& M. R. Dadds (Eds.), The developmental psychopalhology of anxiety. New York: Oxford University Press.

Muris, P., Merckelbach, H., \& Collaris, R, (1997), Common childhood fears and their origins. Behaviour Research and Therapy, $35,929-937$.

Muris, P., Merckelbach, H., Mayer, B., \& Prins, E. (in press). How serious are common childhood fears? Behaviour Research and Therapy.

Muris, P., Merckelbach, H., Meesters, C., \& Van Lier, P. (1997), What do children fear most often? Journal of Behavior Therapy and Experinental Psychiatry, 28, 263-267.

Ollendick, T. H. (1983). Reliability and validity of the revised fear survey schedule for children (FSSC-R). Behaviour Research and Therapy, 21, 685-692.

Ollendick, T. H., Hagopian, L. P., \& King, N. J. (1997). Specific phobias in children. In G. C. L. Davey (Ed.), Phobias. A hantlbook of theory, research and treatment (pp. 201-225). Chichester, England: Wiley.

Ollendick, T. H., \& King, N. J. (1991). Origins of childhood fears: An evaluation of Rachman's theory of fear acquisition. Behaviour Research and Therapy, 29, 117-123.

Ollendick, T. H., \& King, N.J. (1994). Diagnosis, assessment, and treatment of internalizing problems in children: The role of longitudinal data. Journal of Consulting and Clinical Psychology, $62,918-927$.

Ollendick, T. H., \& King, N. J. (1998). Empirically supported treatments for children with phobic and anxiety disorders: Current status. Jounial of Clinical Child Psychology, 27, $156-167$.

Ost, L. G. (1985). Ways of acquiring phobias and outcome of behavioral treatments. Behaviour Research and Therapy, 23, 683689.

Rachman, S. J. (1977). The conditioning theory of fear acquisition: A critical examination. Behaviour Research and Therapy, 15, 375-387.

Rachman, S. J. (1991). Neoconditioning and the classical theory of fear acquisition. Clinical Psychology Review, 11, 155-173.

Silverman, W. K., La Greca, A. M., \& Wasserstein, S. (1995). What do children worry about? Worries and their relationship to anxiety. Child Development, 66, 671-686.

SPSS Inc. (1998). Statistical package for social sciences (Version 8.0) [Computer software]. Chicago: Author.

Stevenson-Hinde, J., \& Shouldice, A. (1995). 4.5 to 7 years: Fearful behaviour, fears and worries. Journal of Child Psychology and Psychiairy, 36, 1027-1038.

Vasey, M. W., Crnic, K. A., \& Carter, W. G. (1994). Worry in childhood: A developmental perspective. Cognitive Therapy and Research, 18, 529-549.

Vasey, M. W., \& Daleiden, E. L. (1994), Worry in children. In G. C. L. Davey \& F. Tallis (Eds.), Worrying: Perspectives on theory, assessment, and reatment (pp. 185-207). Chichester, England: Wiley.

Viemero, V., \& Paajanen, S. (1992). The role of fantasies and dreams in the TV viewing-aggression relationships. Aggressive Behavior, $18,109-116$.

Manuscript received August 10, 1998

Final revision received February 12, 1999 
MURIS, MERCKELBACH, GADET, \& MOULAERT

Appendix

Stories and Pictures Used in This Study

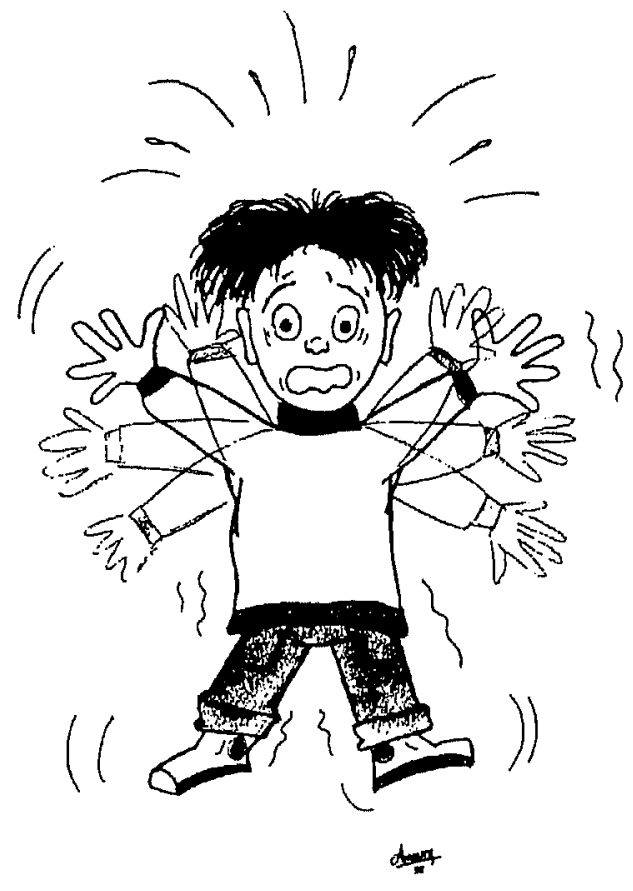

Fears: This child is fearful of something.

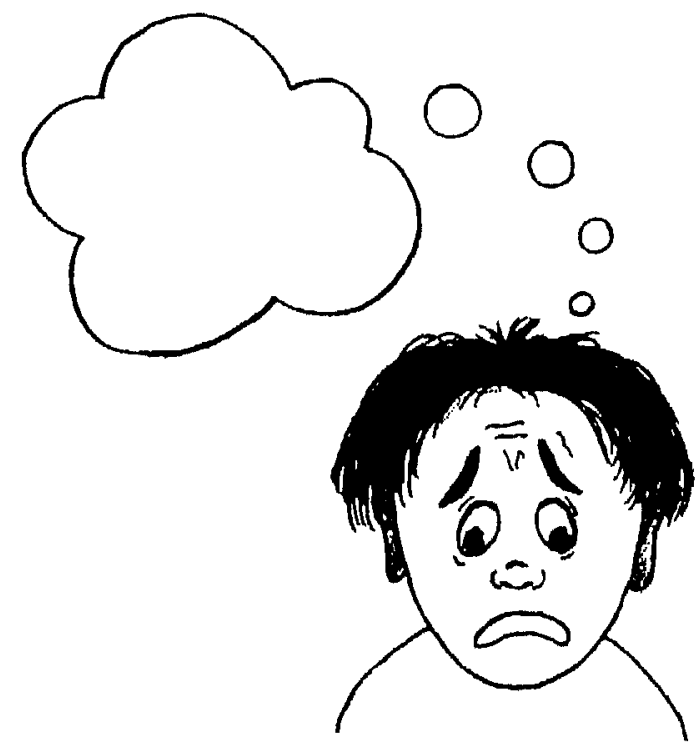

Worries: This child worries about something. He is thinking about a bad thing that may happen.

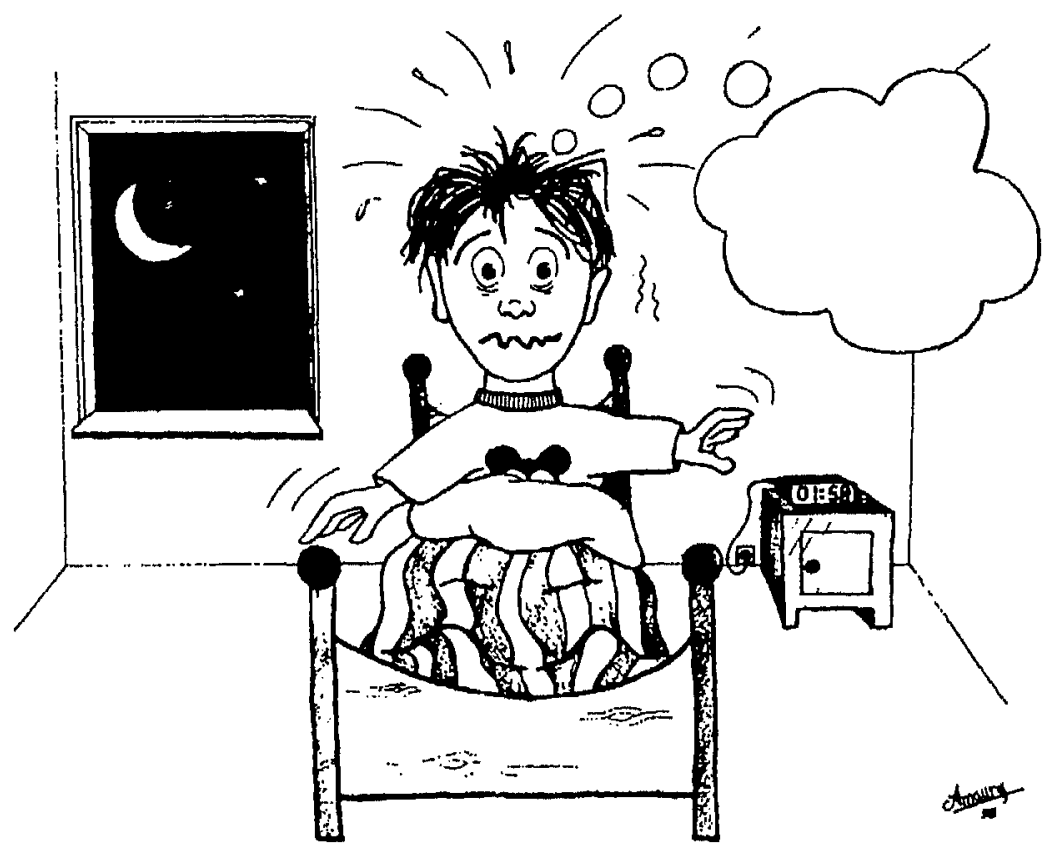

Seary Dreams: It is night. This child was sleeping but suddenly woke up. He had a scary dream. 